Jurnal Sulolipu : Media Komunikasi Sivitas Akademika dan Masyarakat

Vol. 19 No. 12019

e-issn : 2622-6960, p-issn : 0854-624X

\title{
EFEKTIVITAS SERBUK BIJI PEPAYA (Carica papaya) DAN TAWAS DALAM MENGENDALIKAN JENTIK NYAMUK Aedes aegypti
}

\author{
Asmira $U^{1}$ dan Sulasmi ${ }^{2}$ \\ 1.2Jurusan Kesehatan Lingkungan Poltekkes Kemenkes Makassar \\ laksmi.kesling@gmail.com
}

\begin{abstract}
Dengue hemorrhagic disease is a disease caused by Aedes aegypti mosquitoes with a known virus with a dengue name that goes into the human circulation through the bite. Prevention of the spread of DHF can be done by breaking the chain of transmission through larva control. The purpose of this research is to know the effectiveness of papaya seed powder (Carica papaya) and alum in controlling mosquito larvae Aedes aegypti. This type of research is experimental research. The samples in this study were 20 larvae of Aedes aegypti mosquitoes exposed on papaya seed powder (Carica papaya) and alum dose $1 \mathrm{gram}$ papaya seeds, 0.5 gram alum and 2 grams of papaya seeds, 1 gram alum and 3 grams of papaya seeds and alum 1.5 gram, with repetition 3 times for 24 hours. The results showed that the higher the dose of papaya seed powder and alum than the more larva that died. At a dose of 1 gram of papaya seeds with 0.5 grams of larvae which died as many as 20 with LD50 at 540 min. At a dose of 2 grams of papaya seeds with 1 gram alum larvae that died as much as 20 tail with LD50 at 480 min, and at a dose of 3 grams of papaya seed with 1.5 grams of larvae died of 20 tail with LD50 at $420 \mathrm{~min}$. This is due to larvae exposed to papaya seed powder that has chemical content. The conclusion of this research is papaya seed powders and alum is effective in disabling Aedes aegypti mosquito larvae where LD50 has been reached so that papaya seed powder and alum can be recommended in controlling dengue fever vector dengue.
\end{abstract}

Keywords: Papaya seed powder, Alum, Larvae Aedes aegypti dikenal dengan nama dengue yang masuk ke peredaran darah manusia melalui gigitan. Pencegahan penyebaran penyakit DBD dapat dilakukan dengan memutus mata rantai penularan melalui pengendalian jentik. Tujuan dalam penelitian ini adalah untuk mengetahui efektivitas serbuk biji pepaya (carica papaya) dan tawas dalam mengendalikan jentik nyamukAedes aegypti. Jenis penelitian ini adalah penelitian eksperimen. Sampel dalam penelitian ini adalah 20 ekor jentik nyamuk Aedes aegypti yang dipaparkan dengan serbuk biji pepaya (carica papaya) dan tawas dengan dosis 1 gram biji pepaya, 0.5 gram tawas dan 2 gram biji pepaya, 1 gram tawas serta 3 gram biji pepaya dan tawas $1.5 \mathrm{gram}$, dengan pengulangan sebanyak 3 kali selama 24 jam. Hasil penelitian menunjukkan bahwa semakin tinggi dosis serbuk biji pepaya dan tawas maka semakin banyak jentik yang mati. Pada dosis 1 gram biji pepaya dengan 0.5 gram tawas jentik yang mati sebanyak 20 ekor dengan $L_{50}$ pada menit ke-540. Pada dosis 2 gram biji pepaya dengan 1 gram tawas jentik yang mati sebanyak 20 ekor dengan $L D_{50}$ pada menit ke-480, dan pada dosis 3 gram biji pepaya dengan 1.5 gram tawas jentik yang mati sebanyak 20 ekor dengan $L D_{50}$ pada menit ke-420. Hal ini dikarenakan jentik terpapar dengan serbuk biji pepaya yang memiliki kandungan kimia. Kesimpulan penelitian ini adalah serbuk biji pepaya (carica papaya) dan tawas efektif dalam mematikan jentik nyamuk Aedes aegypti dimana $\mathrm{LD}_{50}$ telah tercapai sehingga serbuk biji pepaya dan tawas dapat menjadi salah satu bahan yang dapat direkomendasikan dalam mengendalikan vektor demam berdarah dengue.

Kata kunci : Serbuk biji pepaya, Tawas, Jentik Aedes aegypti

\section{Pendahuluan}

Penyakit demam berdarah adalah penyakit yang disebabkan oleh nyamuk Aedes aegypti dengan virus yang dikenal dengan nama dengue, di masyarakat nama penyakit ini sudah tidak asing lagi dan di Indonesia merupakan menjadi salah satu negara yang mempunyai angka tertinggi terserang penyakit demam berdarah. Demam berdarah dibawa ke Indonesia melalui tranportasi laut sebelum akhirnya berkembang dan menyebar. Secara garis besar ada 4 cara pengendalian vektor yaitu dengan cara kimia, radiasi, biologis, mekanik/pengelolaan lingkungan. (Soegijanto,2006)

Salah satu pemberantasan vektor penularan penyakit DBD yang dapat dilakukan yaitu dengan cara larvasida yang dikenal dengan istilah abatisasi. Larvasida yang biasa digunakan adalah temefos. Namun, penggunaan larvasida dari bahan kimia ternyata menimbulkan banyak masalah baru diantaranya adalah terjadi pencemaran lingkungan seperti pencemaran air dan resistensi serangga terhadap larvasida. Sehingga perlu adanya larvasida yang lebih aman bagi lingkungan yaitu larvasida alami (biolarvasida) (Shadana, dalam Arimaswati,2017)

Larvasida alami dapat ditemukan pada tumbuhan yang didalamnya mengandung senyawa bahan alam yang berfungsi sebagai larvisida alami, yaitu golongansenyawa aktif seperti alkaloid karpaina, tanin, flavonoid, saponin, dan minyak astiri.. Salah satu tumbuhan yang mempunyai kandungan senyawa bahan alam yang bisa kita manfaatkan sebagai larvasida adalah Pepaya.

Selain larvasida alami tawas (Al2(SO4)3) juga dapat digunakan sebagai insektisida terhadap jentik nyamuk Aedes aegypti. Efeklarvasida dari tawas sebanding dengan berbagai insektisida biologi dan kimia serta efektif untuk semua instar 
Jurnal Sulolipu : Media Komunikasi Sivitas Akademika dan Masyarakat

Vol. 19 No.12019

e-issn : 2622-6960, p-issn : 0854-624X

jentik (Preet dan Seema, 2010 dalam Sulastri, 2016). Pada penelitian Dede Wahyu Hutari dkk (2014) dengan menggunakan estrak biji pepaya sebagai larvasida Aedes Aegypti. dengan penggunaan 4 dosis yaitu $10 \mathrm{ml}, 20 \mathrm{ml}, 30 \mathrm{ml}, 40 \mathrm{ml}$, diperoleh hasil dimana dosis $10 \mathrm{ml}$ dengan rerata kematian $35 \%$, dosis $20 \mathrm{ml}$ dengan rerata kematian $55 \%$, dosis $30 \mathrm{ml}$ dengan rerata $83,3 \%$, dan dosis $40 \%$ rarata kematian $99 \%$.

\section{Bahan dan Metode}

\section{Iokasi Penelitian}

Lokasi penelitian dilaksanakandi Laboratorium Air Jurusan Kesehatan Lingkungan Politeknik Kesehatan Makassar.

2. Desain dan Variabel Penelitian

Pengendalian jentik nyamuk Aedes aegypty terhadap beberapa upaya pengendalian yang bisa dilakukan yaitu pengendalian biologis dan kimia. Adapun jenis bahan yang digunakan dalam penelitian ini adalah serbuk biji pepaya dan tawas, dengan dosis serbuk biji pepaya $(1,2$, dan 3 gram) dengan tawas $(0.5,1,1.5$ gram) dengan masing-masing dosis tawas dicampur dengan dosis serbuk biji pepaya, serta disiapkan satu untuk kontrol tanpa perlakuan. Metode larvasida yang digunakan pada berbagai dosis akan dipaparkan pada 20 ekor jentik nyamuk Aedes aegypti yang kematiannya dihitung setiap 60 menit selama 24 jam, penelitian dikatakan berhasil apabila memenuhi kriteria LD50\% dimana kematian jentik nyamuk Aedes aegypti 50\% dalam kurun waktu 24 jam.

Pada penelitian ini mencakup dua variabel yaitu variabel bebas dan variabel terikat, namun yang menjadi pokok dalam eksperimen ini yaitu efektivitas serbuk biji pepaya dalam mengendalikan jentik nyamuk Aedes aegypti.

3. PopulasidanSampel

a. Populasi

Populasi dalam penelitian ini adalah jentik nyamuk Aedes aegypti

b. Sampel

Sampel yang digunakan dalam penelitian ini adalah 20 ekor jentik nyamuk Aedes aegypti setiap unit perlakuan. Dengan pertimbangan untuk eksperimen larva 20 sampai 25 ekor (WHO dalam Nurjannah 2013) Jumlah seluruh sampel yang dibutuhkan sebanyak 240 jentik nyamuk Aedes aegypti untuk tiga kali replikasi.

\section{Pengumpulan data}

\section{a. Data Primer}

Data primer yang dimaksud adalah data penelitian yang diperoleh dari hasil pengujian yaitu

berapa banyak jentik nyamuk Aedes aegypti yang mati setelah ditambahkan serbuk biji pepaya dan tawas dengan dosis yang telah ditentukan.

\section{b. Data Sekunder}

Data sekunder yang dimaksud adalah data yang diperoleh dari hasil studi kepustakaan serta referensi baik dari artikel, jurnal, buku maupun literatu-literatur yang ada hubungannya dengan objek penelitian.

\section{Analisa Data}

Pengolahan data dilakukan dengan menggunakan komputer dibantu dengan alat hitung, data yang diperoleh dari hasil pengamatan saat pelaksanaan eksperimen disajikan dalam bentuk tabel, presentase, dan grafik hasil penelitian disertai urai-urai yang didasarkan pada teori pendukung,kemudian dianalisa secara deskriptif dengan menghubungkan kematian jentik Aedes aegypti dengan kondisi air bersih sebelum dan sesudah penambahan serbuk biji pepaya dan tawas.

\section{Hasil Penelitian}

Tabel 1

Hasil pengamatan jentik nyamuk Aedes aegypti selama 24 jam Dengan Dosis biji pepaya (Carica papaya) 1 gram dengan tawas 0.5 gram

\begin{tabular}{|c|c|c|c|c|c|c|c|}
\hline \multirow[b]{2}{*}{ No } & \multirow[b]{2}{*}{$\begin{array}{l}\text { Waktu } \\
\text { (menit) }\end{array}$} & \multicolumn{4}{|c|}{ Jumlah kematian jentik } & \multirow{2}{*}{$\begin{array}{c}\Sigma \\
\text { Rata- } \\
\text { rata } \\
\text { kem } \\
\text { atian } \\
\text { jenti } \\
\text { k }\end{array}$} & \multirow[b]{2}{*}{$\%$} \\
\hline & & $\begin{array}{l}\text { Re } \\
\text { pli } \\
\text { ka } \\
\text { si I }\end{array}$ & $\begin{array}{c}\text { Re } \\
\text { plik } \\
\text { asi } \\
\text { II }\end{array}$ & $\begin{array}{c}\text { Repli } \\
\text { kasi } \\
\text { III }\end{array}$ & $\begin{array}{c}\text { Ko } \\
\text { ntr } \\
\text { ol }\end{array}$ & & \\
\hline 1 & 60 & 0 & 0 & 0 & 0 & 0 & 0 \\
\hline 2 & 120 & 0 & 0 & 0 & 0 & 0 & 0 \\
\hline 3 & 180 & 0 & 0 & 1 & 0 & 1 & 5 \\
\hline 4 & 240 & 2 & 2 & 2 & 0 & 2 & 10 \\
\hline 5 & 300 & 3 & 4 & 4 & 0 & 4 & 20 \\
\hline 6 & 360 & 5 & 6 & 5 & 0 & 5 & 25 \\
\hline 7 & 420 & 5 & 7 & 6 & 0 & 6 & 30 \\
\hline 8 & 480 & 6 & 8 & 8 & 0 & 7 & 35 \\
\hline 9 & 540 & 8 & 10 & 11 & 0 & 10 & 50 \\
\hline 10 & 600 & 11 & 12 & 13 & 0 & 12 & 60 \\
\hline 11 & 660 & 13 & 15 & 16 & 0 & 14 & 70 \\
\hline 12 & 720 & 16 & 17 & 18 & 0 & 17 & 85 \\
\hline 13 & 780 & 18 & 19 & 18 & 0 & 18 & 90 \\
\hline 14 & 840 & 20 & 20 & 20 & 0 & 20 & 100 \\
\hline
\end{tabular}


Jurnal Sulolipu : Media Komunikasi Sivitas Akademika dan Masyarakat

Vol. 19 No.12019

e-issn : 2622-6960, p-issn : 0854-624X

Tabel 2

Hasil pengamatan jentik nyamuk Aedes aegypti selama 24 jam dengan dosis biji pepaya (Carica papaya) 2 gram dengan tawas 1 gram

\begin{tabular}{|c|c|c|c|c|c|c|c|}
\hline \multirow{2}{*}{ No } & \multirow{2}{*}{$\begin{array}{c}\text { Wak } \\
\text { tu } \\
\text { (me } \\
\text { nit) }\end{array}$} & \multicolumn{4}{|c|}{ Jumlah kematian jentik } & \multirow{2}{*}{$\begin{array}{c}\Sigma \\
\text { Rat } \\
\text { a- } \\
\text { rata } \\
\text { ke } \\
\text { mat } \\
\text { ian } \\
\text { jenti } \\
\text { k } \\
\end{array}$} & \multirow{2}{*}{$\%$} \\
\hline & & $\begin{array}{l}\text { Repl } \\
\text { ikasi } \\
\text { I }\end{array}$ & $\begin{array}{l}\text { Replik } \\
\text { asi II }\end{array}$ & $\begin{array}{l}\text { Replik } \\
\text { asi III }\end{array}$ & $\begin{array}{c}\text { Kontr } \\
\text { ol }\end{array}$ & & \\
\hline 1 & 60 & 0 & 0 & 0 & 0 & 0 & 0 \\
\hline 2 & 120 & 1 & 0 & 0 & 0 & 1 & 5 \\
\hline 3 & 180 & 3 & 2 & 1 & 0 & 2 & 10 \\
\hline 4 & 240 & 5 & 4 & 3 & 0 & 4 & 20 \\
\hline 5 & 300 & 5 & 5 & 4 & 0 & 5 & 25 \\
\hline 6 & 360 & 6 & 7 & 6 & 0 & 6 & 30 \\
\hline 7 & 420 & 8 & 9 & 9 & 0 & 9 & 45 \\
\hline 8 & 480 & 9 & 10 & 11 & 0 & 10 & 50 \\
\hline 9 & 540 & 12 & 12 & 13 & 0 & 12 & 60 \\
\hline 10 & 600 & 15 & 15 & 15 & 0 & 15 & 75 \\
\hline 11 & 660 & 16 & 17 & 16 & 0 & 16 & 80 \\
\hline 12 & 720 & 19 & 20 & 19 & 0 & 19 & 95 \\
\hline 13 & 780 & 20 & 20 & 20 & 0 & 20 & 100 \\
\hline
\end{tabular}

Tabel 3

Hasil pengamatan jentik nyamuk Aedes aegypti selama 24 jam dengan dosis biji pepaya (Carica papaya) 3 gram dengan tawas $1.5 \mathrm{gram}$

\begin{tabular}{|c|c|c|c|c|c|c|c|}
\hline \multirow[b]{2}{*}{ No } & \multirow[b]{2}{*}{$\begin{array}{c}\text { Waktu } \\
\text { (menit } \\
\text { ) }\end{array}$} & \multicolumn{4}{|c|}{ Jumlah kematian jentik } & \multirow{2}{*}{$\begin{array}{c}\Sigma \\
\text { Rata } \\
\text {-rata } \\
\text { kem } \\
\text { atian } \\
\text { jenti } \\
\text { k } \\
\end{array}$} & \multirow[b]{2}{*}{$\%$} \\
\hline & & $\begin{array}{l}\text { Replik } \\
\text { asi I }\end{array}$ & $\begin{array}{c}\text { Re } \\
\text { plik } \\
\text { asi } \\
\text { II }\end{array}$ & $\begin{array}{c}\mathrm{Re} \\
\text { plik } \\
\text { asi } \\
\text { III }\end{array}$ & $\begin{array}{c}\text { Kont } \\
\text { rol }\end{array}$ & & \\
\hline 1 & 60 & 0 & 0 & 0 & 0 & 0 & 0 \\
\hline 2 & 120 & 1 & 2 & 2 & 0 & 2 & 10 \\
\hline 3 & 180 & 3 & 4 & 3 & 0 & 3 & 15 \\
\hline 4 & 240 & 4 & 6 & 5 & 0 & 5 & 25 \\
\hline 5 & 300 & 6 & 8 & 6 & 0 & 7 & 35 \\
\hline 6 & 360 & 8 & 10 & 8 & 0 & 9 & 40 \\
\hline 7 & 420 & 11 & 12 & 11 & 0 & 11 & 55 \\
\hline 8 & 480 & 14 & 14 & 13 & 0 & 14 & 65 \\
\hline 9 & 540 & 17 & 17 & 15 & 0 & 16 & 80 \\
\hline 10 & 600 & 18 & 19 & 17 & 0 & 18 & 90 \\
\hline 11 & 660 & 19 & 20 & 18 & 0 & 19 & 95 \\
\hline 12 & 720 & 20 & 20 & 20 & 0 & 20 & 100 \\
\hline
\end{tabular}

Grafik 1

Hasil pengamatan jentik Aedes aegypti setelah pemajanan serbuk biji pepaya (carica papaya) dan tawas

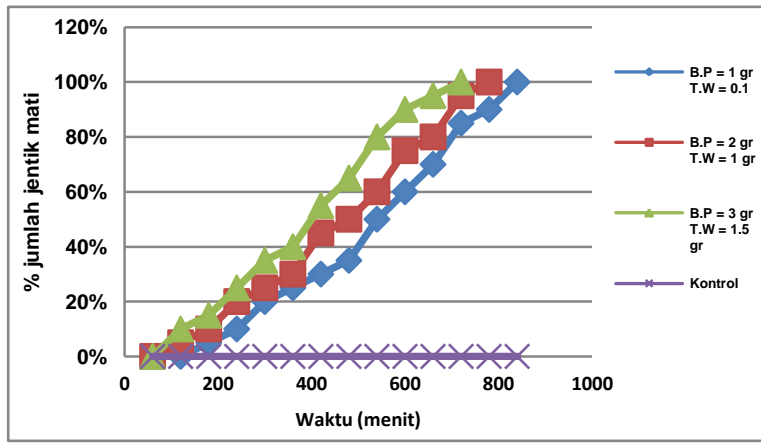

Berdasarkan grafik 4.1 hasil pengamatan serbuk biji pepaya dengan tawas dengan interval waktu pengamatan setiap 60 menit, menunjukkan semakin tinggi dosis yang digunakan maka semakin banyak jumlah jentik Aedes aegypti yang mati.

Kontrol jentik tanpa perlakuan, setelah pengamatan selama 24 jam. Tidak ditemukan nyamuk yang mati. Hal ini dilihat jentik yang ada pada baskom masih bergerak aktif.

Tabel 4

Pemeriksaan pH Pada Serbuk Biji Pepaya (Carica papaya) dan Tawas

\begin{tabular}{|c|c|c|c|c|c|c|}
\hline \multirow[b]{2}{*}{$\begin{array}{l}\mathrm{N} \\
\mathrm{O}\end{array}$} & \multirow[b]{2}{*}{$\begin{array}{l}\text { Dosis } \\
\text { (gram) }\end{array}$} & \multicolumn{3}{|c|}{$\mathrm{pH}$} & \multirow[b]{2}{*}{$\begin{array}{c}\sum \\
\text { Rata } \\
\text {-rata }\end{array}$} & \multirow[b]{2}{*}{$\begin{array}{c}\text { Keterang } \\
\text { an }\end{array}$} \\
\hline & & $\begin{array}{l}\text { Repl } \\
\text { ikasi } \\
\text { I }\end{array}$ & $\begin{array}{c}\text { Replik } \\
\text { asi II }\end{array}$ & $\begin{array}{c}\text { Repl } \\
\text { ikasi } \\
\text { III }\end{array}$ & & \\
\hline 1 & $\begin{array}{c}\text { B.P }=1 \\
T \cdot W= \\
0.5\end{array}$ & 7.23 & 7.26 & 7.25 & 7.24 & \multirow{4}{*}{$\begin{array}{c}\mathrm{pH} \\
\text { memenu } \\
\text { hi } \\
\text { syaratber } \\
\text { dasarkan } \\
\text { Permenk } \\
\text { es RINo } \\
\text { 32 Tahun } \\
2017 \\
\text { yaitu } 6.5 \\
-8.5\end{array}$} \\
\hline 2 & $\begin{array}{l}\text { B.P }=2 \\
\text { T. } W=1\end{array}$ & 7.26 & 7. 02 & $\begin{array}{l}7 . \\
02\end{array}$ & 7.22 & \\
\hline 3 & $\begin{array}{c}\text { B.P }=3 \\
\text { T.W }= \\
1.5\end{array}$ & 7.25 & 7.47 & 7.37 & 7.39 & \\
\hline 4 & Kontrol & 7.77 & 7.07 & 7.43 & 7.63 & \\
\hline
\end{tabular}

Ket : B.P : Biji pepaya

T.W : Tawas 
Jurnal Sulolipu : Media Komunikasi Sivitas Akademika dan Masyarakat

Vol. 19 No.12019

e-issn : 2622-6960, p-issn : 0854-624X

Tabel 5

Pemeriksaan Kekeruhan Setelah Pemajanan Serbuk Biji Pepaya (Carica papaya)Dan Tawas

\begin{tabular}{|c|c|c|c|c|c|c|}
\hline \multirow{2}{*}{ NO } & \multirow{2}{*}{$\begin{array}{l}\text { Dosis } \\
\text { (gram) }\end{array}$} & \multicolumn{3}{|c|}{ Kekeruhan } & \multirow{2}{*}{$\begin{array}{l}\sum \\
\text { Rata } \\
\text {-rata }\end{array}$} & \multirow{2}{*}{$\begin{array}{c}\text { Keteranga } \\
n\end{array}$} \\
\hline & & $\begin{array}{c}\text { repli } \\
\text { kasi } \\
\text { I }\end{array}$ & $\begin{array}{c}\text { Repl } \\
\text { ikasi } \\
\text { II }\end{array}$ & $\begin{array}{c}\text { Repl } \\
\text { ikasi } \\
\text { III }\end{array}$ & & \\
\hline 1 & $\begin{array}{c}\text { B.P }=1 \\
\text { T.W }= \\
0.5\end{array}$ & 2.97 & 2.55 & 3.79 & 3.01 & \multirow{4}{*}{$\begin{array}{c}\text { Parameter } \\
\text { Kekeruhan } \\
\text { memenuhi } \\
\text { syarat } \\
\text { berdasark } \\
\text { an } \\
\text { Permenke } \\
\text { s RI No } 32 \\
\text { Tahun } \\
2017 \text { yaitu } \\
\text { standar } \\
\text { kekeruhan } \\
25 \text { NTU }\end{array}$} \\
\hline 2 & $\begin{array}{l}\text { B.P }=2 \\
\text { T.W }=1\end{array}$ & 3.08 & 3.26 & 3.85 & 3.63 & \\
\hline 3 & $\begin{array}{c}\text { B.P }=3 \\
\text { T.W }= \\
1.5\end{array}$ & 3.89 & 3.97 & 4.24 & 4.03 & \\
\hline 4 & Kontrol & 1.64 & 1.54 & 1.83 & 1.67 & \\
\hline
\end{tabular}

Ket : B.P : Biji pepaya

T.W : Tawas

\section{Pembahasan}

Efektivitas serbuk biji pepaya pada dosis 1 gram dengan tawas 0.5 gram pada menit ke- 180 terdapat 1 ekor jentik yang mati dengan persentase $5 \%$. Dosis kedua yaitu serbuk biji pepaya 2 gram dengan tawas 1 gram tawas pada menit ke-120 terdapat 1 ekor yang mati (5\%) adapun dosis biji pepaya 3 gram dan tawas 1.5 gram terdapat 2 ekor jentik yang mati (10\%) pada menit ke-120.

Hasil tersebut menunjukkan bahwa banyaknya dosis serbuk biji pepaya dan tawas mempunyai daya bunuh yang berbeda pula. Dimana semakin tinggi dosisnya, maka semakin banyak jumlah jentik Aedes aegypti yang mati sampai tingkat konsentrasi tertentu. Dimana pada setiap dosis serbuk biji pepaya dan tawas telah cukup efektif karena telah memenuhi standar $L_{50}$. Dimana lethal Dosis 50 adalah dosis tertentu suatu bahan yang mampu mematikan sebanyak (50\%) hewan percobaan. $\mathrm{LD}_{50}$ secara statistik menyatakan bahwa dosis ini akan membunuh binatang-binatang dengan sensitivitas yang rata-rata hampir sama. (Rahardjo, 2009). Hal ini menunjukkan bahwa semakin banyak zat kimia pada insektisida dalam serbuk biji pepaya maka akan memiliki efek larvasida yang lebih tinggi.

Kematian jentik tersebut dikarenakan biji pepaya (carica papaya) mengandung senyawa kimia dan senyawa aktif seperti alkaloid karpaina, tanin, flavonoid, saponin, dan minyak astiri( $M$.
Ridwan, Dkk. 2016). Zat-zat yang terkandung dalam biji pepaya tersebut bisa berefek sitotoksik, anti androgen atau berefek estrogenik. menimbulkan reaksi kimia dalam proses metabolisme tubuh yang dapat menyebabkan terhambatnya hormon pertumbuhan sehingga jentik tidak bisa tumbuh secara normal. Bahkan akibat dari ketidak mampuan jentik untuk tumbuh akibatnya terjadi kematian. (Iskandar,2015)

Penambahan tawas pada setiap dosis biji pepaya berperan penting dalam proses penjernihan air,sehingga tidak menyebabkan kekeruhan yang signifikan serta tidak mengurangi nilai estetika pada air tersebut, dimana tawas ini berfungsi sebagai bahan koagulan dalam proses penjernihan air(Aziz dkk, 2013 dalam Laila, 2017) dan bahannya pun mudah didapatkan serta bersifat ekonomis. Selain itu tawas juga berperan dalam kematian jentik Aedes aegypti karena dapat menurunkan $\mathrm{pH}$ pada air, penurunan $\mathrm{pH}$ merupakan salah satu faktor yang mempengaruhi kelangsungan hidup jentik Aedes aegypti. Dimana $\mathrm{pH}$ yang terlalu asam diperkirakan dapat menghambat pertumbuhan plankton, sedangkan diketahui bahwa plankton adalah salah satu sumber makanan terbesar untuk jentik, dengan berkurangnya sumber makanan, maka peluang untuk mempertahankan hidup jentik pun menjadi sangat kecil (Erniwati,2014 dalam Sulastri,2016).

Kadar pH pada air berdasarkan Permenkes RI No 32 Tahun 2017 yaitu 6.5 - 8.5.Kadar pH air tersebut aman untuk di konsumsi karena menurut Organisasi Kesehatan Dunia (WHO), tingkat $\mathrm{pH}$ yang sangat tinggi dapat menyebabkan iritasi baik itu di mata ataupu iritasi kulit. sebaliknya juga apabila tingkat $\mathrm{pH}$ terlalu rendah dan berada di bawah 4 dapat menyebabkan efek korosif. Selain memiliki rasa yang tidak enak, air yang asam dengan kadar $\mathrm{pH}$ yang sangat rendah dapat memicu sejumlah masalah yang terjadi di otak dan syaraf. selain itu juga dapat mempengaruhi masalah reproduksi seperti kejang - kejang dan juga menurunnya kemampuan pendengaran bahkan sampai keguguran. (Amin,2017)

Efektivitas serbuk biji pepaya dan tawas dalam mematikan jentik Aedes aegypti disebabkan karena adanya beberapa bahan yang aktif yang terkandung pada serbuk biji pepaya sehingga 
Jurnal Sulolipu : Media Komunikasi Sivitas Akademika dan Masyarakat

Vol. 19 No.12019

e-issn : 2622-6960, p-issn : 0854-624X

menyebabkan kematian terhadap jentik. Hal ini sejalan dengan penelitian (Margo dkk,2017) menunjukkan bahwa serbuk biji pepaya sebagai larvasida dalam mematikan jentik Aedes aegypti efektif pada $200 \mathrm{mg} / 100 \mathrm{ml}$ dalam membunuh $100 \%$ jentik Aedes aegypti selama pemaparan 24 jam.

Biji pepaya (Carica papaya) sebagai larvasida nabati memberikan solusi pelestarian lingkungan, karena larvasida nabati mudah terdegradasi sehingga ramah lingkungan. Selain itu, penggunaan biji pepaya (Carica papaya) ini sangat menguntungkan karena bahannya mudah didapat dan bersifat ekonomis. Begitupun juga dengan tawas selain bahannya mudah didapat dan bersifat ekonomis juga berperan penting dalam proses penjernihan air sehingga tidak mengurangi nilai estetika pada air tersebut.

Pengendalian secara kimia larvasida sintetis seperti misalnya penggunaan serbuk abate pada jentik seringkali dilakukan akan tetapi penggunaan bahan kimia bubuk abate mempunyai sisi negatif pada penggunaannya, dapat menyebabkan pencemaran lingkungan. (Herfiani, 2014 dalam Nurjannah,2013).

Adapun hasil pengukuran $\mathrm{pH}$ dari ketiga dosis dan kontrol adalah berkisar 7,22 sampai 7.63, sedangkan pertumbuhan jentik secara optimal terjadi pada kisaran $\mathrm{pH}$ 6.0-7.5 (Sayono,2011 dalam Yahya 2017). Hal ini menunjukkan hasi pengukuran $\mathrm{pH}$ untuk ketiga dosis tersebut memenuhi pH optimum untuk perkembangan jentik, Sehingga tawas dalam penelitian ini hanya berfungsi untuk menjernikan air. Berdasarkan PERMENKES RI No 32 tahun 2017 standar pH kualitas air bersih adalah 6.5 - 8.5, sedangkan dari hasil pengukuran kekeruhan dari ketiga dosis dan kontrol adalah berkisar 1.67 sampai 4.03. bedasarkan PERMENKES RI no 32 tahun 2017 standar kekeruhan dalam air bersih adalah 25 NTU. $\mathrm{Hal}$ ini menunjukkan tingkat kisaran pHdan kekeruhan pada airsetelah ditambahkan dengan serbuk biji pepaya dan tawas dalam berbagai varian dosis masih memenuhi syarat. dengan demikian biji pepaya dan tawas dapat dimanfaatkan di lingkungan masyarakat.

\section{B. Kesimpulan Dan Saran}

\section{a. Kesimpulan}

Berdasarkan penelitian yang telah dilakukan, serbuk biji pepaya dan tawas efektif dalam mematikan jentik Aedes aegypti sehingga dapat disimpulkan:

Serbuk biji pepaya dosis 1 gram dan tawas 0.5 gram efektif mematikan jentik mencapai (50\%) yaitu 10 ekor.Telah memenuhi Lethal Dosis pada menit ke-540, dosis dosis 2 gram dan tawas 1 gram pada menit ke-480 dan dosis 3 gram tawas 1.5 gram pada menit ke-420.

\section{b. Saran}

1. Kepada pihak yang terkait agar dapat mempromosikan larvasida alami dari serbuk biji pepaya dalam mengendalikan jentik Aedes aegypti.

2. Diharapkan masyarakat dapat memanfaatkan biji pepaya dan tawas sebagai larvasida jentik Aedes aegypti.

\section{DAFTAR PUSTAKA}

Amin Hidayat. 2017. Pengaruh Kadar pH Air Minum Pada Tubuh. Bima. Bima Sakti Jaya. (online) (www.meteran.id/pengaruh-kadar-ph-air-minum-pada-tubuh/ Diakses 6 Juni 2018)

Arimaswati dkk 2017. Efektivitas Bubuk Biji Pepaya (Carica Papaya Linnaeus) Sebagai Larvasida Aedes Sp Instar III. 1Fakultas KedokteranUniversitasHalu Oleo 2 Pendidikan Biologi Fakultas Keguruan dan IImu Pendidikan Universitas Halu Oleo.(Online) (file: I//:/Users/Acer/Downloads/Documents/2808-7816-1-PB_7. Diakses 29 Desember 2017.)

Dede Wahyu Hutari dkk.2014. Efektivitas Bubuk Biji Pepaya (Carica Papaya Linnaeus) Sebagai Larvasida Aedes Sp Instar III. Politeknik Kesehatan Bengkulu, Prodi-DIII Kesehatan Lingkungan. Bengkulu. (Online). (http://keslingbengkulu.blogspot.co.id/2014/08/efektivitas-bubuk-biji-pepaya-carica.html. Diakses 27 Desember 2017)

Iskandar Iwan.2015. Efektivitas Bubuk Biji Pepaya (Carica Papaya Linnaeaus)Sebagai Larvasida Alami Terhadap Kematian Larva AedesAegypty. (online)(file:///C:/Users/Acer/Downloads/Documents /12Article\%20Text-24-1-10-20170428.pdf. Diakses 16 januari 2017)

Laila, Rita Zahara, 2017. Pengaruh Variasi Dosis Tawas Terhadap Kematian Larva Aedes Sp. Undergraduate thesis, Universitas Muhammadiyah Semarang. (Online) (http://repository.unimus.ac. Id/ 1175/ Diakses 1 Januari 2018) 
Jurnal Sulolipu : Media Komunikasi Sivitas Akademika dan Masyarakat

Vol. 19 No.12019

e-issn : 2622-6960, p-issn : 0854-624X

Moko Mauliddin,2015. Penularan dan Siklus Hidup Virus Dengue sebagai Penyebab DBD. (Online) (https://garisbatas.com/penyebab-dan-penularan-dbd/ Diakses 16 januari 2018)

M. Ridwan, Dkk. 2016. Potensi Kemangi sebagai Pestisida Nabati. Makkah: Pendidikan Biologi Universitas Serambi. (Hal.21-25). (Online) (file:///C:/Users/USER/Downloads/112-219-1 SM\%20pdf Diakses 6 Juni 2018)

Nurjanna.P. 2013. Kemampuan Infusa Serbuk Biji Papaya (Carica Papaya L). Terhadap Kematian Larva Aedes Aegypti. Kemenkes RI Politeknik Kesehatan Makassar Jurusan Kesehatan Lingkungan. (KTI tidak diterbitkan)

Sembel Dantje.T, 2009. Entomologi Kedokteran. Yogyakarta. Andi

Soegijanto,Soegeng. 2006. Demam Berdarah Dengue. Surabaya. Unair (AUP).

Sulastri, Widya Hary Cahyati. 2016. Dosis Konsentrasi Tawas (Al2(So4)3) Terhadap Kematian Larva Aedes Aegypti..(Online) (file:///D:/semester \%205/ Metode \%20Penelitian/Proposal/sumber/tawas\%20membunuh\%20jentik.pdf.Diakses 1 januari 2018)

Peraturan Menteri Kesehatan Republik Indonesia Nomor 32 Tahun 2017. Tentang Standar Baku Mutu Kesehatan Lingkungan Dan Persyaratan Kesehatan Air Untuk Keperluan Higiene Sanitasi, Kolam Renang, Solus Per Aqua, Dan Pemandian Umum.

Rahardjo Rio, 2009. Kumpulan Kuliah Farmakologi. Jakarta. Universitas Sri Wijaya. EGC

Yahya, Sulfa Esi Warni. 2017. Daya Tetas Dan Perkembangan Larva Aedes aegypti Menjadi Nyamuk Dewasa Pada Tiga Jenis Air sumur Gali Dan Selokan. Sumatera Selatan. Loka Litbang P2B2 Baturaja, Badan Litbang Kesehatan. Kementerian Kesehatan RI. (online) (ejournal.litbang.depkes.go.id) (Diakses 21 Juni 2018) 